Indeed new privates may emerge to imbue systems with a sharp privateness after old privates have evolved. Thus, the term new private means something more than just the reemergence of a private sector after a period of proscription (the prototypical post-Communist situation) and certainly more than just the emergence of new private institutions within existing private higher education sectors. Of course the exact lines between what qualifies as new private sectors are not always clear-cut.

Daniel C. Levy, Director, PROPHE

\section{Nicaragua: New Private versus Old Private and Public}

\section{Carlos Olivares}

Carlos Olivares is an education specialist at the Inter-American Development Bank, Washington, DC. E-mail: carloso@iadb.org.

\section{$\mathrm{T}$} The quality and relevance of human capital and knowledge generated by higher education is critical to Nicaragua's social and economic development. Private higher education first became available in I960 through the creation of the Central American University. Later in the same decade, the Central American Business Administration University and the Polytechnic University of Nicaragua were founded. In the I990S, 2I new private universities were created; ever since, enrollments in these universities have increased rapidly. Between 200I and 2006, 23 additional new private universities were created. There are a total of 44 new private universities providing access to 65,500 students.

To flesh out the rest of the institutional infrastructure, it should be noted that in the I980 the national public university was divided into two institutions, and later one of them supported the creation of two others. Thus, Nicaragua has four public universities, with 49,900 enrollments. Additionally, six "old private universities," in existence since prior to I990, have 22,060 enrollments. The "old privates" are generally grouped with the four public universities (by the National University Council) as part of the public sector. While (new) private higher education has expanded, the public higher education sector has remained restricted. Thus, the new privates are quickly approaching as many as half the country's enrollments. Even without the old private universities, this is a rather high private-sector proportion by Latin American standards.

\section{Autonomy and Accountability}

In I990, Nicaragua's National Assembly approved law 89, which in the opinion of many critics guarantees an unusual degree of autonomy and a lack of accountability. In accordance with this law, neither public nor private universities are regu- lated by any ministry or other governmental unit. The law divides higher education into "universities" and "higher technical centers." The government subsidizes these institutions directly through the legally mandated 6 percent of the national budget dedicated to higher education. It also founded the National University Council, as a coordinating and consulting entity. The council's only authority with regard to the new private institutions is to authorize their operations. Subsequently, these institutions enjoy total autonomy.

In spite of efforts to make improvements, during the last few years, the subsidized universities have largely remained extremely bureaucratic, with weak planning capacity and outdated didactic methodologies and curriculum contents. The admissions process shows that the secondary school graduates are very unskilled. The majority of applicants attain minimum scores in Spanish and mathematics. Another concern is that few university professors hold doctoral degrees. Most universities function at the periphery of the international scientific community, unable to produce and adapt the knowledge needed to confront the most urgent economic and social problems of the country.

\section{New vs. Old Private Universities}

As throughout Latin America, Nicaragua has been affected by significant expansion of higher education, which has increased the diversity of interests and aspirations of admitted students. Given the failure of Nicaragua's public universities to expand and diversify, dynamic changes in the higher education system have occurred through the large and growing number of new private universities. While these new private institutions tend to be devoted to teaching or training as their main activity,

\section{While these new private institutions tend to be devoted to teaching or training as their main activity, there is much heterogeneity among them.}

there is much heterogeneity among them. Some have existed for Io years or more whereas others are quite young. Teaching, facilities, and infrastructure quality also differs greatly. Enrollment rates range from just Ioo to over 4,000. Some institutions have branches in different parts of the country, and many are family owned. Level of tuition fees also differs greatly.

The old private universities have played an equally important role as have the public universities. Both are top choices for able students and are able to offer scholarships financed with funds from the 6 percent government subsidy. Some new private institutions, despite their small size, have made progress that will likely allow them to assume an important place within the higher education system. Many have introduced new modalities for satisfying enrollment demands. Thus, night classes are common, as are classes on weekends. 
In such ways, the new privates expand access for a population otherwise marginalized. However, the quality of the teaching methods, learning content and programs, remain questionable.

Two years ago, all old privates and publics but only some of new privates carried out a voluntary institutional self-evaluation process, focusing on strengths and weaknesses followed by an external peer review and the drafting of a plan of action. As a result, the majority of the participating institutions are interested in setting up an independent national accreditation system. Several new private universities have already sought accreditation through private regional accreditation agencies. However, most of them are concerned about their ability to meet international accreditation standards and the consequences that may result from failure. While Nicaragua's higher education institutions, especially the new private institutions, are still far from reaching international standards, recent advances hold promise for bringing the country closer to the Latin American region overall.

Nicaragua's new private universities reflect some trends elsewhere in Central America, Latin America more broadly, and even globally. These developments include rapid growth, accommodation where demand exceeds public supply, small institutional size, interinstitutional variation, questionable quality, private finance, and profiles and prospects much in flux.

\section{New Private Universities in}

\section{Nigeria}

\section{ISAAC N. OBASI}

Isaac N. Obasi is a senior lecturer and coordinator of the MPA Program, Department of Political Q Administrative Studies, University of Botswana. Address: Private Bag 0022, Gaborone, Botswana; and a regular columnist on higher education for the Daily Champion newspaper, Lagos, Nigeria. Email: zikobasi@yahoo.com and obasiin@mopipi.bw.

$\mathrm{P}$ ivate universities in Nigeria have evolved during two historical phases. The first phase, during the period of Nigeria's second democratic experiment (1979-1983), private universities emerged without any planning for their development and were later abolished by a military regime in 1984 . Both prior to and during this period, official thinking followed mainly two Presidential Commissions on Higher Education in Nigeria-the Ashby Commission (I962) and the Cookey Commission (I98I) - that were very conservative about the proliferation of universities (public or private).

The second phase in the evolution of private universities (under the present Obasanjo government, I999-) occurred as part of a planned development. Since I999, 24 private universities have been licensed in response to over Ioo applications received by the National Universities Commission, a federal government agency charged with the regulation, accreditation, and monitoring of universities (both public and private).

\section{The New Private Surge}

The first explanation for the new private surge lies with the "public failure theory" expounded in classic literature (e.g., cases of Mexico and Peru) - the problems of public universities, leading to yielding important ground to the emergence of private universities. A second explanation also lies in the literature, but this is "demand absorption," as public supply of higher education falls short of new demand. For example, in I995, the admissions rate of public universities was a scant 6 percent of applications received, and between 1995 and 1998 the average was 16 percent. The private demand-absorbing role is similar to what has happened in some other African countries and elsewhere outside the region.

The third major explanation adapted from elsewhere for the

\section{The first explanation for the new private surge lies} with the "public failure theory"

surge concerns differentiated functions offered by private universities. Taken together, the three reasons fit into broader international higher education reform trends.

\section{EMERGing Features}

In relation to developments in the aborted first phase (1979-I983), the new private universities are a significant improvement. For example, their establishment was meant to conform to some expectations of accreditation standards in areas of staffing, finance, establishment of infrastructure, and provision of facilities and services. Some even have modern facilities not found in their public counterparts. And secondly, in comparison with their public counterparts, the new privates have more cost-effective, lean governance structures rather than the overbureaucratized type of structures. Some are modeled on American-type governance structures as reflected, for example, in the adoption of such nomenclatures as president and vice-president in place of vice-chancellor and deputy vicechancellor. This is also reflected in the adoption of the cost-saving collegiate system in place of the conventional structures of faculties and departments.

The key emerging features of Nigeria's new private universities involve ownership, enrollments, and tuition level. The ownership of private universities in Nigeria is dominated by religious organizations. Of the 24 licensed institutions, I5 are owned by three major religious organizations. The Orthodox/Pentecostal Church organizations have 9 (37.5 per- 